\title{
A románok nevei Anonymus gesztájában és ami körülöttük van
}

\section{3. rész"}

6. adiutorio Cumanorum et Bulgaroum atque Blacorum (c. 44). Az írásom végére hagytam azon kifejezés szemrevételezését, amelyben a három népnév egymás mellett együttesen szerepel. Először nézzük meg a gesztaíró idevágó elbeszélését. A 11. fejezetben olvassuk, hogy „A Maros folyótól Orsova váráig terjedő földet pedig bizonyos Glad nevü fejedelem Bodony várából kiindulva komán segítséggel foglalt el" (quidam dux nomine Glad de Bundyn castro egressus adiutorio Cumanorum ...; Anon. 1999: 18; Anon. 1932: 10; Anon. 1937/1999: 49-50). A 44. fejezet szerint a magyar hadvezérek, Zuardu, Cadusa és Boyta amikor éppen át akartak kelni a Temes folyón, megjelent velük szemben a vidék fejedelme, Glad gyalogosok és lovasok nagy seregével, komán, bolgár és vlach segédcsapatokkal (uenit obuiam eis Glad [...] dux illius patrie cum magno exercitu equitum et peditum adiutorio Cumanorum et Bulgarorum atque Blacorum; Anon. 1999: 38; Anon. 1932: 29; Anon. 1937/1999: 90).

6.1. A három népnév együttes említése az Anonymus szövegére vonatkozó datálási érvek egyikeként is helyet kapott a szakirodalomban. 1883-ban PAULER GyUlA (1883: 113; Anon. 1900: 442, 4. jegyz.; 1. még SEBESTYÉn 1898. 2: 21) - aki szerint Anonymus müve a 12. század végén vagy a 13. század elején íródott megjegyezte, hogy Glad hadainak soraiban a vlachok, a bolgárok és a kománok úgy szerepelnek együtt, mintha csak Anyonymus szeme előtt Kalojan bolgár fejedelem seregei lebegtek volna. MACARTNEY (1940a: 147-148; 1. még I. TóTH 1945/1946: 56) szerint is nehéz elképzelni, hogy a Névtelen 1185 előtt használhatta volna a frázist, és valószínủleg maga vezette be művébe. ERDÉLYI LÁSZLó (1943: 7) a véleményét, miszerint Anonymus III. Béla jegyzője volt, és 1202 és 1204 között írta meg müvét, arra alapozza, hogy a kérdéses passzus szerint az 1204-ben létrejött latin császárságot nem ismeri a gesztaíró, de tudja azt, hogy Rácföld Magyarország határán van, miután Imre király 1202-ben felvette a Szerbia királya címet. GYÖRFFY (1993: 125; 1. még GYÖRFFY 1965: 424, 1970: 4-5) - aki szerint a frázis a 12. század végi állapotokat tükrözi - 1948-as könyvében megerősítette MACARTNEY véleményét Henrik konstantinápolyi latin császár III. Ince pápához 1205-ben intézett levelére való hivatkozással, miszerint Kaloján bolgár cár Blach és Commann népe megtámadta a kereszteseket (1. a fenti 3.1. szakaszt). Érdekes módon GYÖRFFY az utóbbi híradásról már nem szól későbbi tanulmányaiban, valószínüleg azért, mert a Geszta szerinte 1200 körül készült. HORVÁTH JÁNOS (1974: 97) úgy vélekedik, hogy a kérdéses együttes említésben szereplő három nép „,egymással szövetkezve vívta ki a bolgár cárság függetlenségét a bizánci fennhatóság alól 1186-ban”, és ezek „,nem a Temes vidékén uralkodó

*Az 1. és 2. részt 1. MNy. 2021: 10-22, 144-157.

Magyar Nyelv 117. 2021: 309-331. DOI: https://doi.org/10.18349/MagyarNyelv.2021.3.309 
Glad fejedelem népei voltak, s nem is a Temes vidékén volt a hazájuk, hanem az ország határain kívül”. Azt írja továbbá, hogy ezek a kománok (nála kumánok) „már valóban a balkáni-fekete-tengeri kumánok, akik a XIII. század elején háborgatni kezdték az ország déli-délkeleti határvidékeit". KRISTÓ (1978: 657) a szóban forgó frázissal kapcsolatban hasonlóan vélekedik, és leszögezi azt is, hogy „Anonymus ismerte a második bolgár állam etnikai összetételét, tudta, hogy benne a bolgárok és kumánok mellet a blakoknak volt nagy szerepük" (1. még VÁsÁRY 2005: 26).

A kérdéses szóösszetételről tehát nagy vonalakban egyetértés figyelhető meg a szakirodalomban, amely ezt a Második Bolgár Cárság korai szakaszára, a 12-13. század fordulójára vonatkoztatható kifejezésnek tartja. Az Anonymus múvének különböző nyelvü, újabb fordításaihoz készített kommentárokban is gyakran olvassuk ezt. ${ }^{27}$ Azon vélemény, hogy a három népnév együttes említése kormeghatározó jegygyel rendelkezik, amely a Második Bolgár Cárság idejére, mégpedig Kaloján korára vonatkoztatható, első pillantásra meggyőzőnek hangzik. Azonban kétséges, hogy Anonymusnak tudomása lett volna arról, hogy a Bolgár Cárság e három népből tevődött össze, és ezért tudta volna összekötni a hármat. 1967-ben megjelent könyvében CsóKA LAJOS (1967: 430-431) - aki szerint Anonymus az 1150-es években készítette el mủvét - nem tartja bizonyíthatónak azt a véleményt, miszerint Anonymus a szóban forgó kifejezést az 1186-ban létrejött komán-bolgár-vlach (román) szövetség hatására és analógiájára írta volna. Úgy véli, hogy ha a Névtelen a három népet külön-külön ismételten szerepeltethette, akkor egyszer szövetségesekként is említhette őket. Kevésbé valószínű azonban az is, hogy a három népnév együttes említése az ilyen véletlennek lenne köszönhetö, és Anonymus maga komponálta volna, vagy valamiféle szóbeli hagyományból merítette volna a szóban forgó frázist.

A kérdéses passzussal kapcsolatban ezenkívül szólni kell még egy különleges irányzatról, amely a gesztaírónak részlegesen hitelt adva a vlachoknak a 9. századi történetét képzeli el a Kárpát-medencében. Ízelítöül csak IOAN-AUREL POP és ALEXANDRU MADGEARU nézetére utalok, akik könyvükben külön-külön több oldalt szenteltek a Glad-kérdésnek, és akikéhez hasonló nézetet vall több kutató is napjainkban. Csupán a három népnév együttes említésére szorítkozva nézzük meg röviden, hogy az említett két kutató hogyan vélekedik a kérdésröl. POP azt gondolja, hogy kabarok értendők az Anonymusnál szereplö Cumani alatt, de a kérdéses kifejezésben levő Cumani a besenyők jelölésére szolgált (POP 1996: 126; kritikájára 1. KRISTÓ 2002: 12-13). Ezzel az eljárással lehetne visszavinni a kérdéses frázist is a gesztaíró koránál több évszázaddal korábbi állapotra utalóan, történeti tényként. MADGEARU (2005: 34-36; 1. még Anon. 1996: 30, 7. jegyz.; SĂLĂGEAN 2006: 13) szerint a kománok szerepeltetése nem feltétlenül anakronizmus, hiszen e népnév egy másik török népet jelölhet, kabarokat vagy besenyőket, és Glad - bolgár vagy román eredetü - valódi történeti személy lehetett. ${ }^{28}$

${ }^{27}$ Anon. 1991: 171, 256. jegyz.; Anon. 2006: 145, 276. jegyz. Érdekes módon a bolgár fordítás jegyzetében erről nem esik szó, hanem arról, hogy a kománok és a vlachok említése anakronizmus, amelyben Anonymus kora, a 12. század vége tükröződik (Anon. 2001: 48, 226. jegyz.).

${ }^{28}$ KRISTÓ (2003b) joggal cáfolta MADGEARU először 2001-ben románul megjelent monográfiájának mondanivalóját a Geszta románokkal kapcsolatos részeiröl, bár a 2005-ös angol változatát 
Az efféle vélekedésből az következik, hogy a kabar vagy a besenyő időkből származnak a velük együtt említett Blac-ok (vagyis románok) is. ${ }^{29}$ A kománoknak a kabarokkal való azonosságát valló nézet (l. többek között GYÖRFFY 1965: 4) - amely régen kapott hangot a szakirodalomban (vö. SPINEI 2009: 75) - már, komoly alapok nélkül született, túlhaladott hipotézisnek tekintendő. BENKÖ LORÁND (1998: 40-57) meggyőzően rámutatott arra, hogy az Anonymusnál kománnak mondott személynevek nem bizonyítanak közvetlen török kapcsolatokat. Viselöiknek akár kabar, akár besenyő volta szóba sem jöhet. Anonymus az utóbbiakról név szerint tesz említést, az előbbirekől pedig talán fogalma sem volt.

6.2. Valószínúbbnek tartom, hogy a gesztaíró valamely írásbeli dokumentumból kölcsönözte a szóban forgó frázist. Az eddigi kutatás arra a kérdésre is sort kerített, hogy Anonymus írásmúvére milyen külföldi forrásadatok - közvetve vagy közvetlenül - voltak hatással. Az ez irányú kutatások (Anonymus latin nyelvü külföldi forrásainak kérdéséról historiográfiai áttekintést ad THOROCZKAY 2009) közül témánk szempontjából kiemelendő DEÉR JÓZSEFnek a munkája, aki egyebek mellett az Ansbertus neve alatt fennmaradt forrásmüben, a Historia de expeditione Friderici imperatoris címü munkában vélt felfedezni szövegpárhuzamot a Névtelen krónikás írásművének bennünket érdeklő frázisával (DEÉR 1971: 56; 1. még KAPITÁNFFY 2003: 97, 34. jegyz.). A szöveghely Barbarossa Frigyes német-római császár 1189. évi keresztes hadjáratának leírása során bukkan fel, amikor Kalopetrus (Péter) segítséget ígér a császárnak a görögök ellen. A DEÉR által a két írásmüből idézett szöveghelypárhuzamokban tulajdonképpen nincsenek hosszabb egyezések. Ansbertusnál a három népnév (Bulgari, Blaci, Cumani) szerepel ugyan, de a három nem együtt, egymás mellett áll, hanem csak kettő jelenik meg így: a Blacorum et Cumanorum, akik íjjal és nyíllal harcolnak (KKF. 58, 63; LIBI. 3: 279, 283-284). Anonymus szerint pedig a Blasii et Sclaui fegyverzete íjból és nyilakból áll. DEÉR nyomán GYÖRFFY (1990: 121) is arra következtetett, hogy Anonymus olvasta Ansbertus leírását Frigyes császárnak Magyarországon és a Balkánon átvezető útjáról. Egyes kutatók a DEÉR javasolta szöveghelypárhuzamokat nem tartják meggyőzőnek (Anon. 1991: 169, 232. jegyz.; MADGEARU 2005: 17). Megjegyzendő, hogy Ansbertus a vlachokra nem csak a Blac, hanem a Flach alakot is használja (KKF. 28, 33, 35; LIBI. 3: 253,

RICHARD GRZESIK (2016: 30, 15. jegyz.) - aki a Geszta lengyel fordításához (Anon. 2006) jegyzeteket készített - briliánsnak tartja. Ezt az angol változatot MADGEARU maga készítette javítással és kiegészítéssel, bár az idevágó részt illetően nincs lényeges változás. A 2019-ben megjelent új könyvében - amely az Expansiunea maghiară în Transilvania (Magyar expanzió Erdélyben) címet viseli - szintén elismétli ugyanazt a témánkkal kapcsolatos részben (MADGEARU 2019: 104-109). A történész figyelmét nem keltette fel KRISTÓ 1978-as idevágó alapvető tanulmánya, sőt az ennek 2001ben megjelent angol változata (KRISTÓ 2001a) sem, amelyet az angol nyelvủ Anon. 2010. sem említ.

${ }^{29}$ Régebben az ehhez hasonló szemlélet nem ment ritkaságszámba. Például MELICH (19251929: 308-309), hivatkozván a gesztának a három nép együttes említését tartalmazó passzusára, és megjegyezvén azt, hogy Glad seregében oláhok is voltak, felteszi magának a kérdést, hogy vajon milyen nemzetiségü volt és mikor is élt Glad. Felelete: Glad magyar nemzetiségű volt, és a 9. század végén vagy a 10. század első felében élhetett. 
257, 259). ${ }^{30}$ Vajon Anonymus tudása a Bolgár-Vlach Cárság etnikai összetételét illetően nem tủnik-e túl szakszerünek vagy tudományosnak a korabeli tollforgatókéhoz képest? Anonymus felfogása a Balkánon létrejött új politikai képződményről nem térhetett el nagyban a III. Ince pápáétól, miszerint ott Bulgaria et Blachia fekszik, a bolgárok és vlachok uralkodója (dominus Bulgarorum et Blachorum) uralma alatt. Ansbertus mủvében a három nép ugyan egy szöveghelyen szerepel, de a szó szóros értelmében nem egymás mellett, sőt a vlachok (Blaci) és a bolgárok (Bulgari) együttes szerepeltetése uralkodói címben (Kalopetrus, Blacorum [...] Bulgarorum dominus) fordul elö, a vlachok és a kománok együttes említése pedig hadi eseménnyel, a sereg összetételével kapcsolatban. Ansbertus írásának hatására a Névtelen - saját képzelőerejének köszönhetően - vajon egymás mellé tudta-e rakni a három népnevet Glad seregének összetevőiként?

6.3. Véleményem szerint van még egy írott dokumentum, amely hatást gyakorolhatott a Névtelen gesztájára. Igaz ugyan, hogy Villehardouin (GV. 1961. 2: 160-163, §352; GV. 1985: 129) említést tesz arról, hogy Kalojan, Blachia királya (Johannissse, le roi de Blaquie) hadserege vlachokból, bolgárokból és 14000 kománból áll (Blas et Bogres et bien XIIII ${ }^{m}$ Cumains), de nehéz elképzelni, hogy Anonymus erről a hírről tudomást szerzett volna, aki különben sem ebben a sorrendben s névalakban sorolta fel a három népet. Hasonlóképpen nem jöhet szóba az a passzus sem, amely III. Ince 1205 júliusában kelt levelében fordul elö, és amely szerint a vlachok és bolgárok cárja a kománokkal, a törökökkel és a görögökkel együtt a latinok ellen harcolt (Rex quoque Blachorum et Bulgarorum cum Cumanis, Turcis et Grecis adversus Latinos pugnantes; RI. 8: 228-229, 126. sz.; LIBI. 3: 362-363, 34. sz.).

Az 1210-es évek elején zajlott balkáni hadi eseményekről becses információval szolgál azon levél, amelyet a Konstantinápolyi Latin Császárság uralkodója, Flandriai Henrik (1206-1216) intézett minden barátjához (universis amicis) szólva négy ellensége (Boril, Theodor Laszkarisz, Mihály epiruszi despota és Strez [nepos Johannicii]) fölött aratott győzelméröl. A számunkra érdekes frázis a levél azon a szakaszában bukkan fel, amelyben a Henrik és Boril közötti hadakozásokról esik szó. Eszerint amikor Henrik Rossa (Rhusion/Rousion, amely valahol a híres Via Egnatián található) vidékén tartózkodott, megbízható hírnöktől értesült arról, hogy Boril a közelben van kománokból, bolgárokból és vlachokból álló nagy seregével. 1973-ban GÜNTER PRINZING (1973: 397-401, 405-406, 418) - aki szintén 1212-ben keletkezettnek vélte ezen körlevelet, ahogy a korábbi kutatás tette - közzétette ennek a kritikai kiadását három kézirat alapján, amelyeket röviden $\mathrm{B}, \mathrm{C}$ és D-nek nevezett. ${ }^{31} \mathrm{~A}$ legjobbnak a $\mathrm{B}$ másolatot tartotta, megjegyezvén, hogy a B szöveg adja a legteljesebb változatát a tulajdon-

${ }^{30}$ VÁCZY (1974: 35., 101. jegyz.) szerint a hadjáratban részt vevő Ansbertus a népnevet szláv közvetítéssel vlach alakban vette át, amelyet bajor módra írt le (Flach-ra), de 1189 decembere óta, amint a sereg görög környézetbe jutott, a görög alakot (Blac, Blach) használja.

${ }^{31} \mathrm{~B}=$ Bibliothèque royale, Brüssel (II. 1146, f. 100r-101v.); $\mathrm{C}=$ Bibliothèque municipale Valencienne, Franciaország (482, f. 140v-143r.); Bibliothèque royale, Brüssel (21.887, f. $191 \mathrm{v}-194 \mathrm{v}$. 
neveknek és időrendi adatoknak is, így szövegváltozatok kíséretében ezen B vezérkézirat szövegét közölte, amelynek végén ez áll: „Datum Pergamis in octavis Epyphanie anno dominice incarnationis MCCXI". A kutató megjegyzi, hogy a levél dátuma húsvéti évkezdetben (Osterstil-ben, stilus paschalis-ban) van megadva, tehát 1212. január 13-ának felel meg. A C-ben pedig az „Apud Pergamum in octavis Epyphanie anno Domini MCCXII" szerepel, amely PRINZING szerint januári évkezdetben van megjelölve, így a két kézirat közti ellenmondás eltünik. Ezzel szemben 2001-ben FILIP VAN TRICHT (2001: 221-222) felhívta a figyelmet arra, hogy a lacuna a B-hez képest nem nagy a C-ben, lefeljebb két sor hiányzik, és még többek között arra is, hogy a B-ben Blascorum, a C-ben pedig helyesen a Blacorum alak fordul elő. Ami a kronológiai kérdést illeti, a történész felfigyelt arra, hogy a levél dátumhelyén a D-ben évszám nélküli január 13. áll, és mivel a B-s datálási formula (anno dominice incarnationis) Henrik császár más levelei ben - szemben a C-s formulával (anno Domini) - nem fordul elö, arra következtetett, hogy a $\mathrm{C}$ a legjobb a ránk maradt másolatok közül. Szólt arról is, hogy az 1212-es évszám a C-ben húsvéti évkezdetben van megadva, következésképpen szerinte a levél nem 1212., hanem 1213. január 13-án kelt. Ezt a nézetet - amelynek elfogadása esetén néhány balkáni esemény eddigi kronológiája (vö. BÁRÁNY 2012: 136-140) revízióra szorul - magunkévá tehetjük. ${ }^{32}$

A számunkra fontos rész a B kézirat szerint - amelyet PRINZING vezérkéziratként tett közzé - a következőképpen hangzik: „...quod Burillus ibidem prope ante nos erat cum maximo Comanorum et Blascorum et Bulgarorum exercitu et nostro insidias adventui...". A C kéziratban, amelyet VAN TRICHT minősített a legjobbnak, a kérdéses szövegrész következőképpen áll: „... quod Burillus ibidem prope nos erat cum maximo Commanorum et Bulgarorum et Blacorum exercitu et nostro insidias adventui....". ${ }^{33}$ Sőt, hozzátehetjük, hogy a népek felsorolási sorrendje a D-ben is ugyanez: „...Commanorum et Gulgarorum et Blacorum....”. Következésképpen az eredeti levélben is a három népcsoport neve minden bizonnyal a következő sorrendben állhatott: kománok, bolgárok és vlachok, ami összhangban van azzal, ahogyan Béla király jegyzője említette őket: „...uenit obuiam eis Glad [...] dux illius patrie cum magno exercitu equitum et peditum adiutorio Cumanorum et Bulgarorum atque Blacorum".

${ }^{32}$ Egyúttal említést teszünk arról is, hogy a levélnek - amelynek tartalma a bolgár történet szempontjából sem hagyható figyelmen kívül - bilingvis kiadása 1981-ben megjelent Szófiában. Azonban a levél közlésénél BORISLAV PRIMOV - aki egyben a bolgár fordítását is elkészítette jegyzetekkel ellátva - ugyan hivatkozott, de nem támaszkodott PRINZING szövegközlésére, és „főleg” (главно) J. A. C. BUCHON 1840-es szövegkiadását vette alapul. A levél dátumhelye a bolgár kiadásban: „Datum apud Pergamum, die octavis Epiphanie, anno Domini 1212” - amely megegyzik BUCHON (1840: 213) szövegközlésével -, de arról nincs megjegyzés, hogy ez a dátum húsvéti évkezdettel van-e megjelölve vagy sem (LIBI. 18-23; 1. még BožILOV 2017: 334).

${ }^{33}$ KAPITÁNFFY ISTVÁN (2003: 97-98, 34. jegyz.) - utalva az Anonymusnál szereplő három nép együttes említésére - azt írja, hogy az 1200 körüli forrásokban ugyanezek a népek szerepelnek az ekkor születő Második Bolgár Cárság említésekor, és lábjegyzetben hivatkozik Henrik császár levelének kérdéses passzusára is, amelyet a bolgár kiadványból (LIBI. 4: 19) vett át, de ebből további következtetést nem vont le. 
(Egyúttal megemlítjük, hogy Henrik császár ezen levelében a következő szöveghely is megtalálható : ,quod Burillus illuc supervenisset cum magno exerc it u damna nobis plurima inferendo". A ritkítás tőlem: S. T.). A három népnév együttes szerepeltetése Henrik császár levelében - amelyben a császárnak a Thesszalonikéi Latin Királyságban az annak védelmében tett hadviseléséröl is esik szó - figyelemreméltó, hiszen a felsorolási sorrendje teljesen megegyezik az Anonymus Gesztájában előfordulóéval. Nem könnyü elképzelni, hogy a Névtelen csupán az ún. Ansbertus munkájából szerzett ismeretei alapján hat lehetséges variáció közül - véletlenül - éppen ebben a sorrendben rakta a három népnevet egymás mellé, például nem a *Bulgararorum et Blacorum atque Cumanorum vagy * Blacorum et Cumanorum atque Bulgarorum stb. sorrendben. Bizonyosra vehetö, hogy Henrik császár 1213. január 13-i levelének címzettjei között II. András magyar király is ott volt, aki néhány évvel később feleségül vette a császár sógorának, Courtenay Péternek a lányát, Jolántát, és akinek testvére, Margit a Thesszalonikéi Latin Királyság régense volt. Okunk van feltételezni, hogy a gesztaszerző írott információs csatornával rendelkezett a Balkánon folyó hadi eseményekről is, és - még ha ezekben az időkben már nem is volt az udvari kancellária tagja - valamikor 1213 januárja után Henrik császár szóban forgó levelét valamilyen módon megismerhette, keze ügyében lehetett, s ez pedig Glad dux hadakozásának megrajzolásához mintául szolgálhatott a szerző számára.

7. A balkáni hadjáratok leírása Anonymusnál. Eddig az Anonymus Gesztájában említett vlachok neveit vettük szemügyre, különös tekintettel névalakjaikra. Mielőtt sorainkat zárnánk, talán nem haszontalan Glad további hadakozásaira is sort keríteni, amelyekről Anonymus a három népnév együttes említése után szól: „A harc során elveszett a kománok két vezére, a bolgárok három knéze (duo duces Cumanorum et tres kenezy Bulgarorum). Maga Glad fejedelem is megfutott...” A győzelem után a magyar vezérek ,továbbindultak és a bolgár határ közelébe (uersus fines Bulgarorum) értek, ahol a Panyóca vize mellett (iuxta fluuium Panoucea) vertek tábort." Glad Keve várába vette be magát (castrum Kenee ingressus est), amelyet azután békét kérve önként átadott (c. 44; Anon. 1999: 38-39; Anon. 1932: 29-30; Anon. 1937/1999: 91).

Az Anonymus által említett Keve vára (castrum Keuee) - ahova Glad dux vette be magát - III. Ince pápa Imre királyhoz 1204 szeptembere táján intézett levelében is előfordul, amelyben a pápa megrótta a királyt amiatt, hogy megakadályozta a pápai legátus, Leo utazását, akit Bulgáriába és Blachiába küldött a Magyar Királyságon keresztül (in Bulgariam et Blachiam per regnum tuum). A levél szerint Leo a Magyar Királyság határához közeledvén Keve várába (ad castrum, que vocatur Keue) érkezett, ahol csak a Duna választja el a királyságot a bolgár területtől; egy nappal később a király követei hirtelen megjelentek és útját állták, majd a várispántól (a comite castri) is parancs jött, hogy ne nyújtsanak támogatást a legátusnak. (Magyar fordítás: ÍF. 418; RI. 7: 199-200, 126. sz.; LIBI. 3: 348-349; vö. GI. 119-121, c. 78; 1. még PAULER 1899. 2: 34-35, 488., 22. jegyz.; HINTNER 1976: 124-140; Gy. 3: 307, 317. Az első ismert kevei ispán, Achilles 
1201-ből, a kövekező Miklós pedig 1208-ból adatolt; ZsOLDOs 2011: 161; vö. RI. 7: 201, 14. jegyz.) Anonymusnak erről is, valamint feltehetően a fentebb említett vidini hadieseményrő $1^{34}$ is tudomása volt. Ezen katonai esemény során Iwachin ispán a három Komániából való vezérrel (tres duces de Cumania) csatázott - közülük kettőt megöltek -, majd Vidin várába (ad castrum Budin) érkezett, és a lázadó bolgárok lekaszabolták négy rokonát és más vitézeit (RA. 1: 277, 976. sz.; román fordítás: DIR. 338-339; vö. részleges magyar fordítás: KHO. 60-61). BENKÖ (2002: 86-87), jelezve, hogy Glad duxot többen élö, történeti személynek tartják, joggal szögezte le, hogy erre nincs komoly bizonyíték, és Glad személye és neve Anonymus szokványos kitalációja. A Névtelen munkamódszerének ismeretében ezzel csak egyet lehet érteni. Az előadottak fényében - BENKÖ névtani vizsgálatai mellett - vajon van-e még a szakirodalomban azon elképzelésnek helye, miszerint a három népnév együttes említésében szereplő Cumani-n a kabarokat vagy esetleg a besenyőket értsük? Azon törni a fejünket szintén hiába való, hogy a kománokkal együtt említett vlachok (Blaci) hol és mikor éltek, ha tudjuk, hogy Anonymus a Balkán déli részén - valahol a Via Egnatia közelében - harcoló Boril három népcsoportból álló seregét északra hozta mint Glad seregét.

7.1. Anonymusnál zavart okozhatott az a körülmény, hogy létrejött a BolgárVlach Cárság, majd a Konstantinápolyi Latin Császárság és a Thesszalonikéi Latin Királyság, aminek következtében a Bizánc fennhatósága alatt élt népek függetlenedtek a Balkánon. Anonymus leírása a magyar seregek hadjáratairól a Balkánon - amely a Geszta következő, 45. fejezetében olvasható - motívumokban tulajdonképpen nem áll távol III. Ince pápa óhajától, hogy az egyházi unió nevében a római Szentszék befolyása alá kerítse nemcsak Bulgáriát s Blachiát, hanem Rácföldet (Szerbiát) is, sőt a Balkán más területeit, beleértve Durazzót (ma Durrës, Albánia) is. Ahhoz, hogy a bolgár-vlach uralkodó küldöttségei az akkori Bulgária fővárosától, Tirnovótól (та Велико Търново) eljussanak a római Szentszékhez, két útvonal kínálkozott: Szófiától tovább délnyugatra haladva Durazzóig jutnak, és onnan hajóval érik el az Appennini-félszigetet (SWEENEY 1973a: 122), vagy szárazföldön Szófiától északnyugatra veszik útjukat, s a Magyar Királyságon át jutnak el Rómáig. III. Ince 1207. május 25-én kelt levelében közölte Kalojannal, hogy megbízta a magyar királyt (II. Andrást) és a velencei dogét (Pietro Zianit) azzal, hogy a követeket szabadon és biztonságban utaztassák át Magyarországon, illetve Durazzón keresztül (RI. 10: 112, 65. sz.; LIBI. 3: 371, 39. sz.; 1. még HiNTNER 1976: 218-219). Durazzo a velenceiek rövid uralma után 1213 táján az Epiruszi Despotátus kezébe került (DUCELLIER 1981: 150-151).

${ }^{34}$ A katonai esemény ideje szerintem 1213/1214 telére tehető; ezekben az időkben II. András fiának, Bélának hozatott feleséget Bulgáriából (vö. ÉRSZEGI 1975: 96-97). Most csak annyit jegyzek meg, hogy II. András és Boril közeledése csak 1213 januárja volt után lehetséges, amikor Henrik latin császár fenti levele kelt. (Az idevágó időrendi kérdés külön tárgyalást igényel, itt csak néhány újabb tanulmányra utalnék: DIMITROV 1998: 122-125; VÁSÁRY 2005: 59-60; BÁRÁNY 2012: 136-138; NINOV 2013/2014: 139; MADGEARU 2017: 191-192; GEORGIEVA 2015: 340-343. IV. Béla 1250-es oklevele Erdély 13. századi története szempontjából is igen fontos; vö. KRISTÓ 2002: 180-181, 192-193.) 
A gesztaíró további elmesélése szerint a magyar seregek átkeltek a Dunán, bevették Barancs (Borons) ${ }^{35}$ várát, majd Szófia (Scereducy, Szeredőc) vára alá vonultak. Azután pedig ,továbblovagoltak a Bazil kapun túlra és bevették Fülöp király városát (castrum Philippi regis, blg. Пловдив), ${ }^{36}$ majd Neopatrasz városáig (ad Cleopatram ciuitatem; 1. Anon. 1900: 444-445, 4. jegyz.; HOLLER 2012) az egész területet meghódították, és hatalmuk alá vették a Durazzo városától ( $a$ ciuitate Durasu) a Rácföldig (usque ad terram Rachy) terjedő vidéket". (C. 45; Anon. 1999: 39; vö. Anon. 1932: 30-31; Anon. 1937/1999: 92. Az Anonymus említette balkáni helynevekről 1. MELICH 1925-1929: 166-168, 195-205. Érdekes módon Borons, Scereducy, Durasu, Rachy meg Bundyn [Budyn] mind magyar nyelvi alakban vannak, holott ezek mind a Magyar Királyságon kívül feküdtek).

Az Anonymus említette Neopatrasszal (Cleopatras-szal) kapcsolatban HOLLER LÁSZLÓ (2012: 71-73; 1. még MALALAT 2018: 224-226) felhívta a figyelmet arra, hogy II. András nővérének, Margitnak, a Thesszalonikéi Latin Királyság régensének története - aki korábban bizánci császárné volt, és szimpátiát táplált a görög alattvalói iránt - a neopatraszi érsekséggel kapcsolódik össze. Fülöp király városáért pedig, amely a korabeli forrásokban Philippopolis néven volt ismert, a latinok és a bolgárok küzdöttek egymással, és ez a 13. század elején olyan események színtere volt, amelyek felkelthették a magyar király figyelmét. Flandriai Henrik latin császár - akire támaszkodott az említett Margit a férje 1207-ben bekövetkezett halála után - 1208-ban Philippopolisnál győzelmet aratott Boril, ,az Isten egyházának legellenségesebb üldözője" fölött (RI. 11: 333, 202. sz.; LIBI. 3: 372, 40. sz.; 1. még HV. 1948: 34-37; HV. 31-32, § 514-521; KovÁCs 2014: 212), bár úgy tünik, hogy a város a továbbiakban is a bolgárok kezében maradt (DANČEVA-VASILEVA 2009: 130-131; vö. BOŽILOV 2016: 337).

Talán nem érdektelen arról az epizódról is szólni, hogy Villehardouin szerint 1205-ben Kalojan (Johannnis li rois de Blakie et de Bougrie) Henrik latin császár ellen vonulva Szerresz városát is hatalmába kerítette, és megígérte a várvédőknek, hogy épségben távozhatnak Thesszalonikébe, Konstantinápolyba vagy Magyarországra, majd ígéretét megszegve összes javaikat elvétette, köztük a kevésbé értékes szegényeket Magyarországra küldte (GV. 1961. 2: 202-203; GV. 1985: 143-144, § 392-394). Figyelmet érdemel, hogy itt nemcsak a Thesszalonikéi Latin Királyságról és a Konstantinápolyi Latin Császárságról, hanem a Magyar Királyságról is szó esett. Ami Szerbiát illeti, Imre király, aki küzdött azért, hogy ezt

${ }^{35}$ Braničevo (szb.). Valószínü, hogy Barancs vára, amelyet 1204 táján még a bolgárok uraltak (1. fentebb 20. jegyz.), Anonymus gesztája keletkezésekor sem tartozott magyar fennhatóság alá, és a Geszta 44. fejezete szerint a Panyóca vize közelében - bizonyára a Duna - volt a bolgár határ. II. András 1217-es oklevelében (RA. 1: 111,336. sz.) említés történik arról, hogy Vruz kitüntette magát többek között Boronch vára mellett (tam in regno quam extra regnum specialterque iuxta castrum Boronch; HO. 7: 7, 5. sz.). Az, hogy 1217-re Barancs már magyar kézre került-e (ÉrSZEGI 1975: 95, 23. jegyz.) vagy sem (DMITROV 1998: 123, vö. 131, 103. jegyz.), ebből nem tünik ki egyértelmúen.

${ }^{36}$ BENKÖ (2009: 37; 1. még BENKÖ 2003: 165) szerint Anonymus leírása a balkáni hadjárat útvonaláról Fülöp király városáig ,pontosan azonos a Magyarországról Bizáncba vivő középkori hadi, kereskedelmi, követjáró útvonallal, fontos állomásainak abszolút sorrendbeli megnevezése aligha eshetett nehezére a Magiszternek, aki ezt az utat jó néhányszor megjárhatta”. 
uralma alá vonja, 1202-ben felvette a Szerbia királya címet is, de 1204 táján a pápához intézett levelében - amely nem maradt ránk, és amelynek tartalmáról a pápa fentebb idézett válaszleveléből értesülünk - említést tesz arról is, hogy Kalojan (Iannitius) kegyetlenül elpusztította Szerbiát, amely a magyar koronához tartozik (magyar fordítás: ÍF. 422; RI. 7: 204, 126. sz.; LIBI. 3: 352, 29. sz.; GI. 123, c. 79; RA. 68, 212. sz.). Az anonymusi terra Rachy (a névröl 1. MELICH 1909: 387-389, 1925-1929: 166-168; BENKÖ 1998: 73-74) azonban nem lehet teljes mértékben azonos a magyar koronához akkoriban tartozó Szerbiával, hanem vélhetőleg az ettől még délebbre eső, a magyar fennhatóság alá gyakorlatilag még nem került Ras nagyobb területe értendő, ${ }^{37}$ amely az ortodox egyház kebelébe tartozott. Ras (Стари Pac) - amely a mai Novi Pazar közelében fekszik, és a bizánci uralom alatt csupán egy fontos közigazgatási és egyházi központ volt - Stefan Nemanja uralkodása idejétől politikai és vallási központtá vált, és ennek eredményeképpen a név a szerb állam jelölésére is szolgálni kezdett (KALIĆ 1995: 149), és feltehető, hogy az Anonymus említette terra Rachy, vagyis Rácföld ebben az értelemben értendő. ${ }^{38}$ Befejezésül annyit kell még megjegyezni, hogy II. András 1215 vagy 1216 húsvétja idején indított támadást (II.) Stefan Nemanjić ellen (KOMATINA 2014: 128; vö. HARDI 2019: 238-239, 244, 248), 1217-ben pedig az utóbbit III. Honorius pápa megkoronáztatta, ami talán Anonymus tollára is lehetett volna befolyással a magyar seregek balkáni hadjáratának megrajzolásában.

8. Záró gondolat. Az Anonymus által a vlachokra alkalmazott háromféle névalak (plur. Blachii, Blasii, Blaci) alatt a latin képzők elvonásával tulajdonképpen a Blach (nem Blachi), a Blas (nem Blasi) és a Blac etnominák értendők. Közülük egyik sem magyar nyelvi alak, és egyik sem hozható közvetlen kapcsolatba egy szláv vlach (plur. vlasi) névalakkal. A források, amelyekből Anonymus merített ebben a vonatkozásban, két csoportra oszthatók.

1. Egyikük a magyar királyi (Imre király, de főleg II. András korabeli) kancellária írásbeliségével hozható összefüggésbe - amennyiben Anonymus ennek közelében volt -, és azon belül háromféle forrásanyag figyelhető meg. 1. a) A Blach névalak

${ }^{37}$ A DEO. szerzője körülbelül egy évszázaddal később a Rác (< Ras) Királyságról (Regnum [...] Rascie) szólva írja, hogy ennek két része van, a legfőbb részt Rasia-nak mondják, amelyet a Rasia nevü folyóról hívnak így, és amely három tartmányt: Kelmiát, Diokleiát és tengermelléki területet foglalja magába; a másik rész neve pedig Szerbia, amely Magyarország közelében helyezkedik el, és három tartományt: Boszniát, Macsót és Marciát foglalja magába (DEO. 1987-1988: 19-20; DEO. 2013: 120-122; a helynevekről 1. DEO. 2013: 162-164). Bizony a leírás nem felel meg pontosan a 13. század eleji állapotnak, de az elnevezés földrajzi fogalmának kettőségére - még ha hozzávetőlegesen is - jól rávilágít.

38 JovanKA Kalić (1995: 148) azt gondolja, hogy a Geszta III. Béla (1172-1196) idején íródott, így az Anonymusnál szereplő terra Racy-t korai előfordulásnak tekinti, amely Szerbiával egyenértékü elnevezés. Ansbertus mủvében Stefan Nemanja még úgy bukkan fel, mint magni comitis de Seruigia et Crassia (KKF. 29, 31, 33; LIBI. 3: 254, 255, 257), III. Ince pápa 1204-es leveleiben pedig (II.) Stefan Nemanjić megaiupannus Seruie-ként szerepel (RI. 7: 199, 126. sz., 205. 127. sz.; LIBI. 3: 348, 28. sz., 354, 29. sz.), ami arra mutat, hogy ezekben az időkben a Ras (lat. Rascia/Rasia) elnevezés tágabb értelemben még nem igen volt elterjedve a külföldi forrásokban. (Vö. a Spalatói Tamás használta passzust: per regnum Servie que Rasia nuncupatur; HS. 300-301.) 
a Bulgarii et Blachii frázis második elemében szerepel. A III. Ince pápa leveleiben gyakran előforduló ország- és népnév együttese (Bulgaria et Blachia, Bulgarorum et Blachorum stb.) adhatott ihletett Anonymusnak arra, hogy a pápaság által a rómaiak nemzetségéből származóknak tartott bolgárokat és vlachokat Pannóniában szerepeltesse, ahol a rómaiak legelöje volt. 1. b) Ami a Blac névformát illeti, amely egybeesett a Blas többes számú alakjával az ófranciában, a Névtelen az erdélyi vlachokra alkalmazta, tudván azt, hogy ez a magyar királyi kancelláriában használatos, mégpedig a dél-erdélyi vlachok jelölésére. 1. c) A három népnév együttes említését Henrik latin császár leveléből kölcsönözte, amelyet II. András udvarába is elküldtek. Anonymus müve írásakor felhasználhatta mindazokat az információkat e névalakokkal és szóösszetételekkel kapcsolatban, amelyek jegyzői szolgálata idején és az azt követő időkben a tudomására jutottak.

2. A másik csoport a Blas névalakra vonatkozik, amely a negyedik keresztes hadjáratról szóló francia írásmüvekben a balkáni vlachok jelöléséül használt névformával egyezik meg. A gesztaíró, aki francia múveltséggel is rendelkezett, közvetlenül is megismerkedhetett ezzel az elnevezéssel azon magyarországi vallon és francia ajkúakkal való érintkezések során, akiket magyarul olaszok-nak, latinul latini-nak neveztek. Úgy összegezhető, hogy a románok háromféle neve a Névtelen egyfajta fércmunkájának köszönhető, és ugyanakkor arra mutatnak, hogy a románok magyar neve a 13. század elején még csak kialakulófélben volt, különben a gesztaíró rájuk a magyar nyelvi alakot, Olaci/Olachi-t is használta volna ${ }^{39}$ mint a besenyőkre a magyar nyelvi Bisseni névformát, ahogy az II. András kancelláriájának írásbeliségében is megfigyelhető.

A háromféle névalak (Blach, Blas, Blac) együttesen egy bizonyos korjelző jegyet hordoz magában: olyan korszakra - a 13. század első évtizedeire - utal közvetve, amikor a negyedik keresztes hadjárat után egymás után létrejött a Balkánon a Konstantinápolyi Latin Császárság és a Thesszalonikéi Latin Királyság. Anonymus kevés információval rendelkezett a vlachok 12-13. század fordulójánál korábbi történetéről. Ezt a vélekedést alátámasztani látszik az adiutorio Cumanorum et Bulgaroum atque Blacorum (c. 44) kifejezés is, amely Boril bolgár-vlach cár idejére mutat, és ugyanakkor azt sugallja, hogy a Geszta keletkezési ideje legkorábban az 1213 januárja utáni időkre tehető. ${ }^{40}$

39 BREZEANU (1996: 30-31) szerint a románokat jelölö népies magyar forma (olachi) azért hiányzik a gesztából, mert Anonymus a népi hagyománytól tartózkodott. A kérdés nem ilyen természetű, hanem a Geszta írásbafoglalásának időbeli vonatkozásaival és a magyar nyelv hangtörténetével van összefüggésben.

${ }^{40}$ HoRVÁTH JÁNOS (1966: 276), aki Péter győri püspökben látta a Geszta szerzőjét, arra gondolt, hogy az írásmü 1215 és 1217 között keletkezett. KRISTÓ (1994: 36), aki szerint a Romani-n a Gertrúd királynéval Magyarországra érkezett német-római alattvalók köre értendő, úgy véli, hogy a Geszta 1210 körül keletkezett, de 1213-ban készen kellett lennie. HOLLER (2012: 75) KRISTÓ érvelésére is támaszkodva írja, hogy 1212 áprilisa és 1213 márciusa közötti egy év a Geszta befejezésének legvalószínűbb időszaka. FONT MÁRTA (1999: 218) Anonymus Ruszra vonatkozó részeit elemezve megjegyzi, hogy a Gesztának - amelyből a halicsi királyság és az egyházi uniós törekvések tükröződése hiányzik - 1214 elött kellett készen állnia, amikor II. András ez irányú elképzelései körvonalazódhattak. BENKŐ (2003: 165) futólag megemlíti, hogy a Geszta létrejöttének ideje az 
Abból, hogy a II. András korabeli oklevelekben Blac, a IV. Béla korabeliekben pedig Olac/Olach névalak volt használatos a dél-erdélyi vlachok jelölésére, nem következik az, hogy a magyar nyelvben rövid időn belül az elnevezés hangalakja hirtelen megváltozott, hanem csupán a kancelláriai névhasználat változásával van dolgunk. Az elöbbi formában ugyanis idegen nyelvi névalak, az utóbbiban a magyar nyelvi alak tükröződik, amely IV. Béla idejében minden bizonnyal a mai oláh kiejtéséhez hasonló lehetett, és ami már II. András idejében is elkezdődhetett. (GÁLDI [1941: xlv] szerint az oláh szó a 13. század közepén öltött testet.) Noha a források kevés száma miatt nem dönthető el egyértelmüen, hogy az olasz és az oláh szavak közül melyik került be korábban a magyar szókészletbe, valószínü, hogy az olasz lehetett az. Összehasonlításképpen megemlíthetö, hogy az olasz szó helynévként 1181-ből Uloz alakban (Gy. 1: 352; Adatok 31; TESz. 2: 1073), személynévként 1138/1329-böl Vlos Vlas formában (Gy. 1: 892; ÁSznt. 822; Adatok 30) bukkan fel (TESz. 2: 1073; EWUng. 1058; RÁCz 2016: 74-75). Az oláh szóval kapcsolatba hozható személy- és helynévi adatok a 12. századból nincsenek, és csak a 13. század közepén, IV. Béla okleveleiben jelenik meg elöször a mondott magyar nyelvi alak. Mindenesetre az EWUng. adatsorából ki kellene törölni az Anonymustól vett Blac(us)-t - amely nem magyar nyelvi alak - mint az oláh szó első előfordulási adatát. Mellékesen egyúttal megjegyzném, hogy a kérdéses magyar szónak második jelentéseként említett adat („1596 'kroatischer Hirt in Westungarn"”) kiegészítésre szorul (1. BOLLÓK 2013: 512; RÁCZ 2016: 70).

Kulcsszavak: Béla király egykori jegyzője, Gesta Hungarorum, románok, etnonimák, vlach, oláh, olasz.

\section{Hivatkozott irodalom}

Adatok = KRISTÓ GYULA - MAKK FERENC - SZEGFÜ LÁSZLÓ, Adatok „,korai” helyneveink ismeretéhez I. Acta Universitatis Szegediensis de Attila József nominatae. Acta Historica 44. 1973.

Antapodosis = BeCKer, JosePH Hrsg., Die Werke Liudprands von Cremona. 3. Aufl. MGH SS rer. Ger. 41. Hahnsche Buchhandlung, Hannover-Leipzig, 1915: 1-158.

Anon. 1849. $=$ Anonymi Belæ regis notarii de gestis Hungarorum liber. In: Rerum Hungaricarum monumenta Arpadiana. Ed. ENDLICHER STEPHANUS LADISLAUS. Scheitlin \& Zollikofer, Sangalli, 1849: 1-54.

Anon. 1898. = Béla király névtelen jegyzöjének könyve a magyarok tetteiröl. Ford. SzABÓ KÁROLY, a fordítást javította és bevezetéssel ellátta MIKA SÁNDOR. Magyar könyvtár 30. Lampel Róbert, Budapest, 1898.

Anon. 1900 = I. Béla király Névtelen jegyzőjének müve. Közli FEJÉRPATAKY LÁsZló, jegyzetekkel ellátta PAULER GYULA. In: A magyar honfoglalás kútföi a honfoglalás ezredéves emlékére. Szerk. PAULER GYULA - SZILÁGYI SÁNDOR. Magyar Tudományos Akadémia, Budapest, 1900: 381-463. [Reprint kiadás: Nap Kiadó, Budapest, 2000.]

1210-es évekre tehető. Ha az 1213/1214-es vidini hadjárat is tükröződik Glad hadakozásainak leírásában, feltehető, hogy a Geszta 1214 után készült. 
Anon. 1932. = P. magister qvondam Bele regis Hvngarie notarivs, Gesta Hvngarorvm. Ed. LADISLAUS JUHÁSZ. Bibliotheca scriptorum medii recentisque aevorum saec. XIIXIII. Királyi Magyar Egyetemi Nyomda, Budapest, 1932.

Anon. 1934/2010. = Faptele ungurilor de secretarul anonim al regelui Bela. Izvoarele istoriei românilor 1. Traducere de G. POPA-LISSEANU, ediţie îngrijită şi prefaţă de IONEL OPRIŞAN. Editura Saeculum I. O., Bucureşti, 2010.

Anon. 1937/1999. = P. magistri, qui Anonymus dicitur, Gesta Hungarorum. Praefatus est textumque recensuit AEMILIUS JAKUBOVICH. Annotationes exegeticas adiecit DESIDERIUS PAIS. In: SRH. 1: 13-117.

Anon. 1943. = Anonymus 1203. In: ERDÉLYI 1943: 9-57.

Anon. 1975. = Anonymus Gesta Hungarorum. Béla király jegyzőjének könyve a magyarok cselekedeteiről. Ford. és jegyzetekkel ell. PAIS DEZSÖ. A bevezetőt írta, a jegyzeteket kieg. és a térképet tervezte GYÖRFFY GYÖRGY. Hasonmás kiadásban megjelentette a Magyar Helikon, Budapest, 1975.

Anon. 1988. = Děje Uhrů mistra P., řečeného Anonymus. In: Legendy a kroniky koruny uherské. Texty z latinských originálů přeložily DAGMAR BARTOŇKOVÁ a JANA NECHUTOVÁ. Výbor uspořádal, úvodní studii, úvody k jednotlivým dílům, komentáře a poznámky napsal, bibliografii a rejstř́ik sestavil RICHARD PRAŽÁK. Vyšehrad, Praha, 1988: 169-260.

Anon. 1991.= Die Gesta Hungarorum des anonymen Notars. Die älteste Darstellung der ungarischen Geschichte. Hrsg. von GABRIEL SILAGI unter Mitarb. von LÁSzLÓ VESZPRÉMY. Ungarns Geschichtsschreiber 4. Thorbecke, Sigmaringen, 1991.

Anon. 1996. = Cronica Notarului Anonymus, Faptele Ungurilor (traducere de pe fotocopia originalului de la Viena), traducere şi comentariu de PAUL LAZĂR TONCIULESCU. Editura Miracol, Bucureşti, 1996.

Anon. 1999. = Anonymus, A magyarok cselekedetei. In: Anonymus, A magyarok cselekedetei. Kézai Simon, A magyarok cselekedetei. Anonymus müvét VESZPRÉMY LÁSzló, Kézai Simon művét BollóK JÁNOS ford., az utószót és a jegyzeteket VESZPRÉMY LÁSZLÓ írta. Osiris, Budapest, 1999: 7-86.

Anon. 2000. = Kronika anonymného notára král'a Bela. Gesta Hungarorum. Prelož., poznámkami a registrom doplnil a úvod. štúdiu napísal VINCENT MúCSKA. Rak, Budmerice, 2000.

Anon. 2001. = Анонимен автор. Деяния на унгариите. Увод и бележки: ХР. ДимитРОВ и ИЛ. ИЛИЕВ, текст и превод: ИЛ. ИЛИЕВ. In: LIBI. 5/1: 13-62.

Anon. 2006. = Anonimowego notariusza króla Béli Gesta Hungarorum. Tł. AlEKSANDRA KULBICKA - KRZYSZTOF PAWŁOWSKI - GRAŻYNA WODZINOWSKA-TAKLIŃSKA. Wstęp i przypisy RYSZARD GRZESIK. Societas Vistulana, Kraków, 2006.

Anon. 2010. = Anonymi Bele regis notarii Gesta Hungarorum. Ed., transl. and annot. by MARTYN RADY and LÁSZló VeSZPRÉMY. Central European medieval texts 5. Central European University Press, Budapest, 2010.

ARMBRUSTER,ADOLF 1990.DerDonau-Karpatenraum in den mittel-undwesteuropäischen Quellen des 10.-16. Jahrhunderts. Eeine historiographische Imagologie. Studia Transylvanica 17. Böhlau, Köln-Wien, 1990.

ÁSznt. = Fehértói Katalin, Árpád-kori személynévtár 1000-1301. Akadémiai Kiadó, Budapest, 2004. 
AunER MiHÁly 1916. Latinus. Századok 50: 28-41.

BÁRÁNY ATTILA 2012. II. András balkáni külpolitikája. In: KERNY TERÉZIA - SMOHAY ANDRÁs szerk., II. András és Székesfehérvár. Székesfehérvári Egyházmegyei Múzeum, Székesfehérvár. 129-173.

BÁRCZI GÉZA 1958a. A magyar szókincs eredete. 2., bőv. kiad. Tankönyvkiadó, Budapest. BÁRCZI GÉZA 1958b. Magyar hangtörténet. 2., bőv. kiad. Tankönyvkiadó, Budapest.

BENKÖ LORÁND 1998. Név és történelem. Tanulmányok az Árpád-korról. Akadémiai Kiadó, Budapest.

BENKÖ LORÁND 2002. Az ómagyar nyelv tanúságtétele. Perújítás Dél-Erdély korai Árpád-kori történetéröl. Társadalom- és müvelődéstörténeti tanulmányok 29. Magyar Tudományos Akadémia, Budapest.

BENKÖ LORÁND 2003. Beszélnek a múlt nevei. Tanulmányok az Árpád-kori tulajdonnevekröl. Akadémiai Kiadó, Budapest.

BENKÖ LORÁND 2009. A Szovárd-kérdés. Fejezetek egy ómagyar nemzetség történetéböl. Akadémiai Kiadó, Budapest.

BINDER PÁL 1995. Havaselve vajdaság megalakulásának dél-erdélyi előzményei és következményei (13-14. század). Századok 129: 1123-1153.

BoBA, IMre 1991. Commentationes ad Anonymi Belae regis Gesta Hungarum. In: Varia Eurasiatica. Festschrift für Professor András Róna-Tas. [Szerk. nélkül.] Department of Altaic Studies, Szeged. 13-21.

BOBA, IMRE 1995. Vlachs in the history of Central Europe. A „Problemstellung”. In: KoszTA LÁSzLó szerk., Kelet és Nyugat között. Tanulmányok Kristó Gyula tiszteletére. Szegedi Középkorász Mühely, Szeged. 95-102.

BODOR GYÖRGY 1976. Egy krónikás adat helyes értelmezése. Magyar Nyelv 72: 268-271. BOLlÓK JÁNOS 2013. Az oláh szó etimológiája. In: MÉSZÁRos TAMÁs szerk., Philologia Nostra. Bollók János összegyüjtött tanulmányai. ELTE Eötvös József Collegium, Budapest. 505-514.

BožILOV, I. [БожИЛОВ, ИВАН] 2017. История на средновековна България 2. Християнска България. Фондация Българско историческо наследство, Пловдив.

BREZEANU, StELIAN 1996. „Romans” and „Blachi” with „Anonymous”. Transylvanian Review 6/2: 15-43.

BREZEANU, STELIAN 1999. „Români” și „Blachi” la Anonymus. Istorie și ideologie politică. In: BrezeAnu, Stelian, Romanitatea orientală în evul mediu. De la cetățenii romani la națiunea medievală. All Educational, București.

BuCHON, J.-A.-C. 1840. Recherches et matériaux pour servir à une histoire de la domination française aux XIII ${ }^{e}$, XIV et $X V^{e}$ siècles dans les provinces démembrées de l'Empire grec à la suite de la quatrième croisade. Deuxième partie. Auguste Desrez, Libraire-Éditeur, Paris.

BUJÁK GÁBOR 2019. Keresztény magyarok gesztája. In: BODA ATTILA szerk., Interdiszciplinaritás a Kárpát-medencében I. Külhoni magyar doktorandusz hallgatók konferencia elöadásaiból. Debrecen, 2018. április 6. ELTE Márton Áron Szakkollégium, Budapest. 407-424.

BuSUIOC VON HASSELBACH, DAN NICOLAE 2000. Țara Făgăraşului în secolul al XIII-lea. Mănăstirea cisterciană Cârța 1-2. Bibliotheca Rerum Transsilvaniae 26. Centrul de Studii Transilvane - Editura Fundaţiei Culturale Române, Cluj-Napoca. 
CAMARA, IOSIF 2019. „Blachii ac pastores romanorum”. De nouveau sur le destin du latin à l'est. Swedish Journal of Romanian Studies 2/1: 109-123. https://doi.org/10.35824/ sjrs.v2i1.18962

CDES. = Codex diplomaticus et epistolaris Slovaciae 1. Ed. RICHARD MARSINA. SAV., Bratislavae, 1971.

ČEKIN, L. S. [Л. С. ЧЕКИН] 1993. Текст воспроизведен по изданию: „Описание земель“. Анонимный географический трактат второй половины XIII в. Средние века 56: 206-225.

Ciocîltan, VirgiL 1996. Observations concernant les Roumains dans la Chronique du Notaire Anonyme du roi Bela. Transylvanian Review 6/2: 3-14.

COLKER, MARVIN L. 1979. America rediscovered in the thirteenth century? Speculum 54: $712-726$.

CurTA, Florin 2016. Constantinople and the Echo Chamber. The Vlachs in the French Crusade Chronicles. Medieval encounters 22: 427-461. https://doi.org/10.1163/ 15700674-12342232

CVetković, MiLoš [Цветковић, Милош] 2018. О статусу Влаха Хеладе у тематском систему. Зборник радова Византолошког института 55: 45-64.

CSÁKÓ JUDIT 2019-2020. A rómaiak pannóniai legelője. Megjegyzések egy hagyomány keletkezéséhez (I-II. rész). Fons. Forráskutatás és történeti segédtudományok 26: 147-192; 27: 119-156.

CSAPODI CSABA 1978. Az Anonymus-kérdés története. Gyorsuló idő. Magvető, Budapest. CSÓKA J. LAJOS 1967. A latin nyelvü történeti irodalom kialakulása Magyarországon a XI-XIV. században. Irodalomtörténeti könyvtár 20. Akadémiai Kiadó, Budapest.

DALl'AGLIO, FrAnCESCO 2019. Rex or Imperator? Kalojan's Royal Title in the Correspondence with Innocent III. Studia Ceranea 9: 171-185. https://doi.org/10.18778/ 2084-140x.09.10

DanČEVA-VAsileva, А. [ДАНЧЕВА-ВАСИЛЕВА, АНИ] 2009. Пловдив през средновековието (IV-XIV век). Академично издателство „Проф. Марин Дринов“, София.

DARKÓ JENÖ 2002. „Pascua Romanorum”. Adalékok a honfoglalás előtti Pannónia településföldrajzához. In: NOVÁK LÁSZLÓ FERENC szerk., Gazdálkodás az Alföldön. Acta Musei de János Arany nominati 9. Arany János Múzeum, Nagykőrös. 33-41.

Daskalov, Roumen 2015. Feud over the Middle Ages. Bulgarian-Romanian Historiographical Debates. In: DASKALOV, RoumEN -VEZENKOV, AlEXANDER ed., Entangled Histories of the Balkans. Volume Three. Shared Pasts, Disputed Legacies. Balkan Studies Library 16. Brill, Leiden-Boston. 274-354. https://doi. org/10.1163/9789004290365_005

DEÉR, JoseF 1931. Ungarn in der Descriptio Europae Orientális. Mitteilungen des Instituts für österreichische Geschichtsforschung 45: 1-22. https://doi.org/10.7767/ miog.1931.45.jg.1

DEÉR JÓZSEF 1943. A románság eredetének kérdése a középkori magyar történetírásban. In: DEÉr JózSEF - GÁldI LÁSZló szerk., Magyarok és románok 1. Budapest. 94110 .

DEÉR, JoseF 1971. Aachen und die Herrschersitze der Arpaden. Mitteilungen des Instituts für österreichische Geschichtsforschung 79: 1-56. https://doi.org/10.7767/ miog.1971.79.12.1 
DELETANT, DENNIS 1991. Ethnos and mythos in the history of Transylvania. The case of the chronicler Anonymus. In: Deletant, DenNis, Studies in Romanian history. Editura Enciclopedică, Bucureşti. 332-351.

DEO. 1913. = Anonymi descriptio Europae orientalis. Imperium Constantinopolonanum, Albania, Serbia, Bulgaria, Ruthenia, Ungaria, Polonia, Bohemia - anno MCCCVIII exarata. Ed., praef. et adnotationibus instruxit OLGIERD GÓRKA. Sumptibus Academiae Litterarum, Kraków, 1913.

DEO. 1934/2010. = Geograful anonim, Descrierea Europei Orientale. Traducere de G. POPA-LISSEANU, ediţie îngrijită şi prefaţă de IONEL OPRIŞAN. Izvoarele istoriei românilor 2. Editura Saeculum I. O., Bucureşti, 2010.

DEO. 1987-1988. = BORZÁKNÉ NACSA MÁRIA - SZEGFÜ LÁSZLÓ, Egy Délkelet-Európát bemutató földrajzi munka a XIV. század elejéről. (Descriptio Europae Orientalis.) A Juhász Gyula Tanárképzö Főiskola tudományos közleményei. Tanulmányok a marxizmus-leninizmus és a történettudomány köréböl 1987-1988: 13-27.

DEO. 2013. = Anonymi descriptio Europae Orientalis. Anonymov opis istochne Evrope. TiBOr ŽIVKOVIĆ -VladeTA PETROVIĆ - AleKsANDAR UdELAC. Kritično izdanje teksta na latinskom jeziku prevod i filoloshka analiza DRAGANA KUNČER, urednik SRĐAN RUDIĆ. Istorijski Institut, Beograd, 2013.

DHV. = Documenta historiam Valachorum in Hungaria illustrantia usque ad annum 1400 p. Christum curante Emerico Lukinich etadiuvante LADISLAO GÁLDI; ed. ANTONIUS FEKETE NAGY, LADISLAUS MAKKAI. Ostmitteleuropäische Bibliothek 29. Instituti Historici Europae Centro-Orientalisin Univ. Scientiarum Budapestinensis, Budapest, 1941.

Dimitrov, CH. [Димитров, ХРИсто] 1998. Българо-унгарски отношения през Средновековието. Академично издателство „Проф. Марин Дринов”, София.

DIR. = Documente privind istoria României: veacul XI, XII şi XIII: C. Transilvania Vol. 1 (1075-1250) comit. de red. ION IONASCU et al. Editura Academiei Republicii Populare Române, Bucureşti, 1951.

DuCELlier, Alain 1981. La façade maritime de l'Albanie au Moyen Age. Durazzo et Valona du XIe au XVe siècle. Institute for Balkan Studies, Thessaloniki.

ECKHARDT SÁNDOR 1927. Vallon-francia írásjelek emlékeinkben. Magyar Nyelv 23: 571572.

ERDÉLYI LÁSZLÓ 1943. Krónikáink magyarul. Városi Nyomda és Könyvkiadó, Szeged.

ÉRSZEGI, GÉZA 1975. Eine neue Quelle zur bulgarisch-ungarischen Beziehungen während der Herrschaft Borils. Bulgarian Historical Review 3/2: 91-97.

EO. = Erdélyi okmánytár. Oklevelek, levelek és más írásos emlékek Erdély történetéhez 1-[4]. Szerk. JAKÓ Zsigmond, [4.] HEGYI GÉZA - W. KovÁCS ANDRÁs. Akadémiai Kiadó etc., Budapest, 1997-[2015].

ESz. = Etimológiai szótár. Főszerk. ZAICZ GÁBOR. A Magyar Nyelv Kézikönyvei 12. Tinta Könyvkiadó, Budapest, 2006.

EWUng. = Etymologisches Wörterbuch des Ungarischen 1-2. Hrsg. BENKÖ, LORÁND. Akadémiai Kiadó, Budapest, 1993-1995. + Register. Akadémiai Kiadó, Budapest, 1997.

FONT MÁRTA 1999. Anonymus „Ruscia”-képének alapjai és forrásértéke. In: KLANICZAY GÁBOR - NAGY BALÁZS szerk., A középkor szeretete. Történeti tanulmányok Sz. Jónás 
Ilona tiszteletére. ELTE BTK Közép- és Koraújkori Történeti Tanszék, Budapest. 207-218.

FrEIBERGS, GUNAR 1999. The „Descriptiones Terrarum”. Its date, sources, author and purpose. In: Kloczowski, Jerzy- Kras, PAWEL- Polak, WoJcIECH ed., Christianity in East Central Europe. Late Middle Ages. Proceedings of the Commission Internationale d'Histoire Ecclésiastique Comparée, Lublin 1996. Instytut Europy Środkowo-Wschodniej Lublin, Lublin, 2: 180-201.

GÁldi, LADISLAUS 1941. Le nom des Roumains dans les chartes latines de Hongrie. In: DHV. xli-xlvii.

GeORGIEVA, SASHKA 2015. Bulgarian-Hungarian marital diplomacy during the first half of the thirteenth century. Bulgaria Mediaevalis 6: 339-355.

GI. = The Deeds of Pope Innocent III by an Anonymous. Translated with an introduction and notes by JAMES M. POWELL. Catholic University of America Press, Washington D. C., 2004.

GRZESIK, RYSZARD 2016. Blasi and Pastores Romanorum in the Gesta Hungarorum by an Anonymous Notary. Res Historica 41: 25-34. https://doi.org/10.17951/rh.2016.0.25

GV. 1961. = Geoffroi de Villehardouin, La conquête de Constantinople 1-2. Éditée et traduite par EDMOND FARAL. 2e éd. rev. et corr. Les classiques de l'histoire de France au moyen âge 18-19. Les Belles lettres, Paris, 1961.

GV. 1985. = Geoffroy de Villehardouin, Bizánc megvétele. Ford. és a jegyzeteket írta SzABICS IMRE, az utószót KozMA BÉLA írta. Európa, Budapest, 1985.

Gy. = GYÖRFFY GYÖRGY, Az Árpád-kori Magyarország történeti földrajza 1-4. Akadémiai Kiadó, Budapest, 1963-1998.

GYÓNI MÁTYÁs 1989. A kievi ősévkönyv volochjai. Századok 123: 298-342.

GYÖRFFY GYÖRGY 1964. Adatok a románok XIII. századi történetéhez és a román állam kezdeteihez 1-2. Történelmi szemle 7: 1-25, 537-568.

GYÖRFFY GYÖRGY 1965. Honfoglalás előtti népek és országok Anonymus Gesta Hungarorumában. Ethnographia 76: 411-431.

GYÖRFFY GYÖRGY 1970. Anonymus Gesta Hungarorumának kora és hitelessége. Irodalomtörténeti Közlemények 74: 1-13.

GYÖRFFY GYÖRGY 1990. A magyarság keleti elemei. Gondolat, Budapest.

GYÖRFFY GYÖRGY 1993. Krónikáink és a magyar őstörténet. Régi kérdések új válaszok. Balassi, Budapest.

GYÖRY JÁNOS 1948. Gesta regum - gesta nobilium. Tanulmány Anonymus krónikájából. Az Országos Széchényi Könyvtár kiadványai 29. Országos Széchényi Könyvtár, Budapest.

HARDI, ĐURA [ХАРДИ, ЂУPA] 2019. О дипломатској мисији Светог Саве код угарског краља Андрије II. Crkvene studije 16: 235-248.

P. HIDVÉGI ANDREA 1951. A magánhangzók labializációja Anonymus magyar szórványaiban. Magyar Nyelvjárások 1: 95-117.

Hintner, DieTMar 1976. Die Ungarn und das byzantinische Christentum der Bulgaren im Spiegel der Register Papst Innozenz’ III. St. Benno-Verlag, Leipzig.

HO. = Hazai okmánytár / Codex diplomaticus patrius 1-8. Kiadják: 1-5. NAGY IMRE PAUR IVÁN - RÁTH KÁROLY - VÉGHELY DEZSŐ. Sauervein, Győr, 1865-1873. 6-8. 
IPOLYI ARNOLD - NAGY IMRE - VÉGHELY DEZSÖ. Franklin, Budapest, 1876-1891. [Hasonmás kiadás: Jókai Mór Városi Könyvtár, Pápa, 2004.]

Holler LÁSzló 2012. Anonymus és „Kleopátra városa”. Helynévtörténeti Tanulmányok 8: $61-80$.

HÓMAN BÁLINT 1917-1918. A magyar nép neve és a magyar király címe. Történeti Szemle 6: 129-158, 240-258; 7: 1-22.

Horger ANTAL 1925. Oláh és olasz. Magyar Nyelv 21: 175-180.

HoRVÁTH JÁNOS 1966. P. mester és műve. Irodalomtörténeti Közlemények 70: 1-53, 261-282.

HoRVÁTH JÁnOs 1974. Anonymus és a Kassai Kódex. In: HoRVÁTH JÁNOS - SzÉKelY GYÖRGY szerk., Középkori kútföink kritikus kérdései. Memoria saeculorum Hungariae 1. Akadémiai Kiadó, Budapest. 81-110.

HS. = Thomae Spalatensis Spalatensis Historia Salonitanorum atque Spalatinorum pontificum. Ed., transl. and annot. by DAMIR KARBIC - MIRJANA MATIJEVIC SOKOL JAmes Ross SweEney. Latin text by OlgA PERIĆ. Central European medieval texts 4. Central European University Press, Budapest - New York, 2006.

HV. 1948. Henri de Valenciennes, Histoire de l'mpereur Henri de Constantinople. Publié par JEAN LONGNON. Documents relatifs à l'histoire des croisades 2. Libraire Orientaliste Paul Geuthner, Paris, 1948.

HV. 2009. Анри дьо Валансиен, История на император Анри. Превод от старофренски ИВАЙЛО БУРОВ, Предговор КРАСИМИР ГАГОВА. Полис, София.

ÍF. = Írott források az 1116-1205 közötti magyar történelemröl. Az előszót írta, a szövegeket vál., a kötetet szerk. THOROCZKAY GÁBOR. Szegedi középkortörténeti könyvtár 28. Szegedi Középkorász Mühely, Szeged. 2018.

IORGA, NiCOLAE 1921. Les plus anciennes chroniques honroises et le passé des Roumains 1. Bulletin de la Section Historique. Académie Roumaine 9/3-4: 193-223.

Kalić, Jovanka 1995. Rascia. The Nucleus of the Medieval Serbian State. In: The Serbian question in the Balkans. Ed. and transl. by DUŠANKA HADŽI-JOVANČIĆ. Faculty of Geography. University of Belgrade, Belgrade. 147-155.

KAPITÁNFFY ISTVÁN 2003. Hungarobyzantina. Bizánc és a görögség középkori magyarországi forrásokban. Typotex, Budapest.

KENYHERCZ RÓBERT 2013. A szókezdö mássalhangzó-torlódások az ómagyar korban: a helynevek hangtörténeti forrásértéke. A Magyar Névarchívum Kiadványai 28. Debreceni Egyetemi Kiadó, Debrecen.

KESZLER BORBÁLA 1969. A szókezdő mássalhangzótorlódások feloldása korai jövevényszavainkban. Nyelvtudományi Értekezések 63. Akadémiai Kiadó, Budapest.

KHO. = Középkori históriák oklevelekben. 1002-1410. A szöveget vál., az elöszót és jegyzeteket írta KRISTÓ GYULA 2., átd. kiad. Szegedi középkortörténeti könyvtár 1. Szegedi Középkorász Mühely, Szeged, 2000.

KIRÁLY PÉTER 1987. A VIII-IX. századi Ungraus, Hungaer, Hunger, Hungarius, Onger, Wanger személynevek. Magyar Nyelv 83: 162-180, 314-331.

KISS GERGELY 2013. 11-13. századi magyar föpapok francia kapcsolatai. In: GYÖRKÖS ATTILA - KISS GERGELY szerk., Francia-magyar kapcsolatok a középkorban. Debreceni Egyetemi Kiadó, Debrecen. 341-350. 
KKF. = CHROUST, ANTON Hrsg., Quellen zur Geschichte des Kreuzzuges Kaiser Friedrichs I. MGH SS rer. Germ. N. S. 5. Weidmannsche Buchhandlung, Berlin, 1928.

KleIN, Karl KURT 1963. Latini in Siebenbürgen. In: KleIn, KarL KuRT, Transsylvanica. Gesammelte Abhandlungen und Aussätze zur Sprach- und Siedlungsforschung der Deutschen in Siebenbürgen. Buchreihe der Südostdeutschen Historischen Kommission 12. Verlag R. Oldenbourg, München. 226-255.

KNIEZSA IsTVÁN 1952. Helyesírásunk története a könyvnyomtatás koráig. Nyelvészeti tanulmányok 2. Akadémiai Kiadó, Budapest.

KOMATINA, I. [КОмАТИНА, ИвАНА] 2014. Историјска подлога чуда̂ Светог Симеона у Житију Симеоновом од Стефана Првовенчаног. Зборник радова Византолошког института 51: 111-134.

KonOVAlOVA, IRINA 2020. Images of countries in the anonymous Description of Eastern Europe. In: СВАКА, ДЮЛЫ общ. ред., Россия и Венгрия в мировой культуре: источник и его интерпретация. Материаль двенадиатой международной научной конференции будапештского Центра русистики. 20-21 мая 2019 г. Russica Pannonicana - Аквилон, Будапешт-Москва. 101-109.

KoraĆ, DUŠAN - RADIĆ, RADIVOJ [КОРAЋ, ДУчШАН -РАДИЋ, РАДИВОJ] 1998. Из Каракорума у Бар. Србија у делу анонимног европског географа XIII века. Зборник радова Византолошког института 37: 247-257.

KovÁCS SzILVIA 2014. A kunok története a mongol hóditásig. Magyar Östörténeti Könyvtár 24. Balassi, Budapest.

KRISTÓ GYULA 1978. Rómaiak és vlachok Nyesztornál és Anonymusnál. Századok 112: 623-661.

KRISTÓ GYULA 1994. A történeti irodalom Magyarországon a kezdetektöl 1241-ig. Irodalomtörténeti Füzetek 135. Argumentum, Budapest.

KRISTÓ, GYULA 2001a. Romans and Vlachs in the works by Nestor and Anonymus. Specimina nova. Pars prim., Sectio mediaevalis 1: 15-57.

KRISTÓ GYULA 2001b. Anonymus a 9. századi Kárpát-medence bolgár fejedelmeiről. Acta Universitatis Szegediensis. Acta historica 113: 11-19.

KRISTÓ GyULA 2002. A korai Erdély. 895-1324. Szegedi középkortörténeti könyvtár 18. Szegedi Középkorász Mühely, Szeged.

KRISTÓ GYULA 2003a. Nem magyar népek a középkori Magyarországon. Lucidus, Budapest.

KRISTÓ GYUla 2003b. Románok (újra) Pannóniában? Acta Universitatis Szegediensis. Acta historica 117: 17-25.

KS. 1999a. = Kézai Simon, A magyarok cselekedetei. In: Anonymus, A magyarok cselekedetei. Kézai Simon, A magyarok cselekedetei. Anonymus múvét VeszPrÉmY LÁszló, Kézai Simon múvét BollóK JÁNOS ford. Az utószót és a jegyzeteket VESZPRÉMY LÁSZLÓ írta. Osiris, Budapest. 87-173.

KS. 1999b. = Simonis de Kéza Gesta Hungarorum. Ed. and transl. by LÁSZLÓ VESZPRÉMY and Frank SCHAER. With a study by JENŐ SzÜCS. Central European University Press, Budapest.

LEUMANN, MANU 1977. Lateinische Laut- und Formenlehre. Lateinische Grammatik von MANU LEUMANN -JOHANN BAPTIST HofmANN - ANTON SzANTYR. Bd. 1. Handbuch der Altertumswissenschaft Abt. 2. T. 2. C.H. Beck, München. 
LIBI. = Латински извори за българската история 3, 4, 5/1. Българската академия на науките, София 1965, 1981, 2001.

Macartney, Carlile Aylmer 1940a. Studies on the Early Hungarian Historical Sources III. Études sur 1'Europe Centre-Orientale 21. Sárkány Nyomda, Budapest.

MacArtney, CARlile AYlmer 1940b. „Pascua Romanorum”. Századok 74: 1-11.

MAdgearu, AleXANDru 2001. Românii în opera Notarului Anonim. Bibliotheca Rerum Transsilvaniae 27. Centrul de Studii Transilvane - Editura Fundaţiei Culturale Române, Cluj-Napoca.

Madgearu, AleXANDru 2005. The Romanians in the Anonymous Gesta Hungarorum. Truth and Fiction. Center for Transylvanian Studies - Romanian Cultural Institute, Cluj-Napoca.

MAdGEARU, AlEXANDRU 2017. The Asanids. The political and military history of the second Bulgarian Empire (1185-1280). East Central and Eastern Europe in the Middle Ages 41. Brill, Leiden-Boston. https://doi.org/10.1163/9789004333192

MAdgeArU, AleXANDru 2019. Expansiunea maghiară în Transilvania. Editura Cetatea de Scaun, Târgovişte.

MALAMUT, ÉLISABETH 2018. Marguerite-Marie de Hongrie, imperatrice byzantine et reine latine de Salonique (1185-1223). Byzantinoslavica 76: 213-229.

MÁLYUSZ ELEMÉR 1973. Királyi kancellária és krónikaírás a középkori Magyarországon. Irodalomtörténeti Füzetek 79. Akadémiai Kiadó, Budapest.

MARKOV, N. [MАРКОВ НикОЛАЙ] 2016. Бележки за някои недобре решени проблеми в книгата на Александру Маджяру „Asăneștii. Istoria politico-militară a statului dinastiei Asan (1185-1280) Târgoviște”. In: ПАВЛОВ, ПЛАМЕН-КЪНЕВ, НИКОЛАЙХрисимов, НиколАЙ Съcm., Великите Асеневци. Абагар, Велико Търново. 114-121.

MELICH JÁNOS 1909. Néhány magyar népnévröl. Magyar Nyelv 5: 292-303, 337-344.

MELICH JÁNOS 1925-1929. A honfoglaláskori Magyarország. A magyar nyelvtudomány kézikönyve 1. köt., 6. füz. MTA, Budapest.

MELICH JÁNOS 1963. Dolgozatok 2. Nyelvtudományi Értekezések 41. Akadémiai Kiadó, Budapest.

MirditA, ZEF 2004. Vlasi u historiografiji. Hrvatski institut za povijest, Zagreb.

NinOV, V. [Нинов, ВАСил] 2013-2014. Сведения за бунта във Видин срещу цар Борил (1207-1218) в унгарски кралски грамоти. Bulgaria Mediaevalis 4-5: 131-139.

PALIGA, SorIn 2015. Sclavi, Bulgari, Blachi [sic!] ac pastores Romanorum. In: Omagiu profesorului Ioan Rebușapcă la 80 de ani. Volum coordonat de Constantin Geambașu. Editura RCR Editorial, București. 467-476.

PAPACOSTEA, ŞERBAN 1998. Between the Crusade and the Mongol Empire. The Romanians in the 13th century. Bibliotheca rerum Transsilvaniae 22. Center for Transylvanian Studies - Romanian Cultural Foundation, Cluj-Napoca.

PAULER GYULA 1883. Anonymus külföldi vonatkozásai. Századok 17: 97-116.

PAUlER GYUlA 1899. A magyar nemzet története az Árpádházi királyok alatt 1-2. Atheneum, Budapest. [Reprint: ÁKV, Budapest, 1984.]

Petruchin, V. ЈА. [ПЕТРУХИН, ВЛАДИМИР ЯКОБЛЕВИЧ] 2011. „Русь и вси языци”” Аспекты исторических взаимосвязей. Историко-археологические очерки. Языки славянских культур, Москва. 
Pillon, Michel 2005. Les Daces, Trajan et les origines du peuple roumain. Aspects et étapes d'une controverse européenne. Anabases. Traditions et réceptions de l'Antiquité 1: 75-106. https://doi.org/10.4000/anabases.1303

POHL, WALTER 2017. Walchen, Römer und 'Romanen'. Einleitung. In: POHL, WALTER HARTL, INGRID - HAUBRICHS, WolfGANG Hrsg., Walchen, Romani und Latini. Variationen einer nachrömischen Gruppenbezeichnung. Variatinonen einer nachrömischen Gruppenbezeichung zwischen Britannien und dem Balkan. Forschungen zur Geschichte des Mittelalters 21. Verlag der Österreichischen Akademie der Wissenschaften, Wien. 9-26.

POKORNY, RUDOLF 1985. Zwei unedierte Briefe aus der Frühzeit des Lateinischen Kaiserreichs von Konstantinopel. Byzantion 55: 180-209.

POP, IOAN-AUREL 1996. Romanians and Hungarians from the 9th to the 14th century. The genesis of the Transylvanian medieval state. Bibliotheca rerum Transsilvaniae 13. Centrul de Studii Transilvane - Fundaţia Culturală Română, Cluj-Napoca.

Pop, IOAN-Aurel - ŞIRoş, Sorin 2012. Silviu Dragomir et le dossier du Diplôme des chevaliers de St. Jean. Académie Roumaine, Cluj-Napoca.

PRINZING, GÜNTER 1973. Der Brief Kaiser Heinrichs von Konstantinopel vom 13. Januar 1212. Byzantina 43: 395-431.

PVL. 2007. = Повесть временных лет. Подгот. текста, пер., статьи Д. С. ЛиХАЧЕВА, под. ред. В. П. АДРИАНОВОЙ-ПЕРЕТц. 3-е изд. Наука, Санкт-Петербург, 2007.

PVL. 2015. = Régmúlt idők elbeszélése. A Kijevi Rusz első krónikája. Ford. FERINCZ ISTVÁN. Szerk. BALOGH LÁSZLÓ - KOVÁCS SzILVIA. Magyar Östörténeti Könyvtár 30. Balassi, Budapest, 2015.

RA. = Az Árpád-házi királyok okleveleinek kritikai jegyzéke 1-2. Szerk. SzENTPÉTERY IMRE - BORSA ISTVÁN. MTA - Akadémiai Kiadó, Budapest, 1923-1987.

RÁCZ ANITA 2016. Etnonimák a régi magyar településnevekben. A Magyar Névarchívum Kiadványai 37. Debreceni Egyetemi Kiadó, Debrecen.

RAYNAUD DE LAGE, GUY 1975. Introduction a l'ancien français. $9^{e}$ éd. Société d'édition d'enseignement supérieur, Paris.

RI. = Die Register Innocenz' III. 1-[13]. Bearb. von OTHMAR HAGENEDER et al. Verlag der Österreichischen Akademie der Wissenschaften, Wien. 1964-[2015].

RiCKARD, PETER 1989. A history of the French language. 2nd rev. ed. Unwin Hyman, London-Boston.

ŠACHMATOV, А. А. [ШАХМАТОВ, АЛЕКСЕЙ АЛЕКСАНДРОВИЧ] 1919. Древнейшие судьбЫ русского племени. Издание Русского исторического журнала, Петроград.

SălăgeAn, Tudor 2006. Ţara lui Gelou. Contribuţii la istoria Transilvaniei de Nord în secolele IX-XI. Argonaut, Cluj-Napoca.

SCHÜNEMANN, KONRAD 1926. Die „Römer” des anonymen Notars. Ungarische Jahrbücher 6: 448-457.

Sebestyén GyUla 1898. Ki volt Anonymus? 1-2. Szerzői kiadás, Budapest.

SOLYMOSI LÁSZLÓ 1997. A pápai kancellária hatása a magyarországi oklevéladásra a 13. század közepéig. Történelmi Szemle 39: 335-334.

Soulis, George C. 1963. The Thessalian Vlachia. Зборник радова Византолошког института 8: 271-273. 
SPINEI, ViCTOR 2009. The Romanians and the Turkic nomads north of the Danube Delta from the tenth to the mid-thirteenth century. East Central and Eastern Europe in the Middle Ages 450-1450. Vol. 6. Brill, Leiden-Boston.

SRH. = Scriptores rerum Hungaricarum tempore ducum regumque stirpis Arpadianae gestarum 1-2. Edendo operi praefuit EMERICUS SZENTPÉTERY. Az utószót és a bibliográfiát összeáll., valamint a függelékben közölt írásokat az 1. kiad. anyagához illesztette és gond. SzOVÁK KORNÉL és VESZPRÉMY LÁSZLÓ. 2., bőv. repr. kiad. Nap Kiadó, Budapest, 1999.

STABILE, GIUSEPPE 2010. Valacchi e Valacchie nella letteratura francese medievale. Esercizi di lettura 14. Edizione Nuova Cultura, Roma.

SulyoK, HedVIG 1994. Quasi Latini, In: OlAJOS, THÉRÈSE réd., Byzance et ses voisins. Mélanges à la mémoire de Gyula Moravcsik à l'occasion du centième anniversaire de sa naissance. Acta Universitatis Szegediensis de Attila József nominatae. Opuscula byzantina 9. JATE, Szeged. 93-108.

SweENEY, JAMES Ross 1973a. Basil of Trnovo's journey to Durazzo. A note on Balkan travel at the beginning of the 13th century. The Slavonic and East European review 51: $118-123$.

SWEENEY, JAMES Ross 1973b. Innocent III, Hungary and the Bulgarian coronation. A study in medieval papal diplomacy. Church History 42: 320-334. https://doi. org $/ 10.2307 / 3164389$

SzABADOS GYÖRGY 2003. Kalojan, egy ,román nemzeti hős”. Birodalmi tudat a formálódó Második Bolgár Cárságban. In: WeISz BoGLÁRKA szerk., Középkortörténeti tanulmányok. A III. Medievisztikai PhD-konferencia (Szeged, 2003. május 8-9.) elöadásai. Szegedi Közpkorász Mühely, Szeged. 139-150.

SZÉKELY GYÖRGY 1972. A székesfehérvári latinok és vallonok a középkori Magyarországon. In: KRALOvánszKy Alán szerk., Székesfehérvár évszázadai 2. Az István Király Múzeum Közleményei 14. Székesfehérvár. 45-72.

SzófSz. = BÁRCZI GÉZA, Magyar szófejtő szótár. Budapest, 1941. [Hasonmás kiadás: Trezor Kiadó, Budapest, 1994.]

TAMÁS LAJOS 1935. Rómaiak, románok és oláhok Dácia Trajánában. Magyar Tudományos Akadémia, Budapest.

TĂUTU, LOUIS 1964. Le conflit entre Johanitsa Asen et Eméric roi de Hongrie (1202-1204). (Contribution à l'étude du problème du second empire valaque-bulgare.) In: Mélanges Eugène Tisserant Vol. 3. Orient Chrétien. Studi e testi 233. Biblioteca apostolica vaticana, Città del Vatiano. 367-393.

TESz. = A magyar nyelv történeti-etimológiai szótára 1-3. Főszerk. BENKÖ LORÁND. Akadémiai Kiadó, Budapest, 1967-1976. + Mutató. Akadémiai Kiadó, Budapest, 1984.

THOROCZKAY GÁBOR 1994-1996. Az Anonymus-kérdés kutatástörténeti áttekintése (1977-1993) 1-2. Fons. Forráskutatás és történeti segédtudományok 1: 93-149, 2: $117-173$.

THOROCZKAY GÁBOR 1999. Anonymus latin nyelvű külföldi forrásai. Historiográfiai áttekintés. Turul 72/3-4: 108-117. 
C. TÓTH NORBERT 2001. A Győr-nemzetség az Árpád-korban. In: NeUMANN TiBOR szerk., Analecta Mediaevalia 1. Tanulmányok a középkorról. Argumentum Kiadó Pázmány Péter Katolikus Egyetem, Budapest-Piliscsaba. 53-72.

I. TÓTH ZoLTÁN 1945-1946. Tuhutum és Gelou. Hagyomány és történeti hitelesség Anonymus müvében. Századok 79-80: 21-84.

VÁCZY PÉTER 1974. Anonymus és kora. In: HORVÁTH JÁNOS - SZÉKELY GYÖRGY szerk., Középkori kútföink kritikus kérdései. Memoria saeculorum Hungariae 1. Akadémiai Kiadó, Budapest. 13-37.

VAN TRICHT, FILIP 2001. La politique étrangère de l'empire de Constantinople, de 1210 à 1216. Sa position en Méditerranée orientale: problèmes de chronologie et d'interprétation. Le Moyen Âge 107: 219-238, 409-438. https://doi.org/10.3917/rma. 073.0409

VÁSÁRY ISTVÁN 2001. Népnév és néptörténet (kun/kuman, kipcak, kangli, tatár). In: MÁRTON ALFRÉD szerk., A Kárpát-medence és a steppe. Magyar Östörténeti Könyvtár 14. Balassi, Budapest. 186-195.

VÁSÁRY, ISTVÁN 2005. Cumans and Tatars. Oriental military in the Pre-Ottoman Balkans, 1185-1365. Cambridge University Press, Cambridge.

VERES KRISTÓF GYÖRGY 2019. A magyar királyi kancellária okleveles gyakorlata 1172 és 1235 között. Turul 92: 1-26.

VESZPRÉMY LÁSZLÓ 1992. Anonymus Gestájának kézirata (tizenöt ábrával). Magyar Könyvszemle 108: 44-52.

VESZPRÉMY LÁSZLÓ 2019. Történetirás és történetírók az Árpád-kori Magyarországon (XI-XIII. század közepe). Line Design Kiadó, Budapest.

Zimmermann, Harald 2000. Der Deutsche Orden im Burzenland. Eine diplomatische Untersuchung. Studia Transylvanica 26. Böhlau, Köln-Weimar-Wien.

ZOLNAY LÁSZLÓ 1960. Az esztergomi latinusokról. Esztergom évlapjai 1: 155-167.

ZsOLdos ATTILA 2011. Magyarország világi archontológiája 1000-1301. MTA Történettudományi Intézete, Budapest.

\section{The names for the Romanians in Gesta Hungarorum and what surrounds them}

The three names for Vlachs (plur. Blachii, Blasii, Blaci) used by Anonymus (the anonymous notary of King Béla III), by removing the Latin endings, are actually the ethnonyms Blach (not Blachi), Blas (not Blasi) and Blac. None of them is a Hungarian language form (>oláh), and none of them can be directly related to the Slavic form, vlach (plur. vlasi > olasz). The author of the Gesta Hungarorum, who acted in official affairs not only when he was a notary but also in later times, could use his information in writing his chronicle. Anonymus refers to the lord of Transylvania, Gelou, as the prince of the Vlachs (dux Blacorum), which is in harmony with the fact that the form Blaci was used to denote the Vlachs of southern Transylvania in the charters of King Andrew II. Considering that the Latin literacy of Hungary was influenced by the papal chancellery, it is not surprising that the phrase Bulgarii et Blachii was modelled on the terms used in the papal chancellery, especially in the letters of Pope Innocent III, in which Bulgarians and Vlachs appear together (Bulgaria et Blachia, Bulgarorum et Blachorum, etc.). Anonymus borrowed the phrase Cumanorum et Bulgarorum atque Blacorum from a circular letter of the Latin emperor Henry of Flanders, which 
was also sent to the court of King Andrew II in 1213. The name Blas, which corresponds to the name used in French writings on the Fourth Crusade to denote Balkan Vlachs, was used for the Transylvanian Vlachs by Anonymus, who was in contact with the Walloon and French-speaking settlers in Hungary. The chronicler probably drew the three names in question from the sources of the first two decades of the 13 th century.

Keywords:Gesta Hungarorum, Romanians, ethnonyms, xenonyms, vlach, oláh, olasz. 